\title{
Assessment of the microbiological quality of recreational waters: indicators and methods
}

\author{
Carla Rodrigues $^{1}$ (1) Maria Ângela Cunha ${ }^{2}$
}

Received: 3 November 2016/ Accepted: 4 September 2017/Published online: 14 September 2017

(c) Springer International Publishing AG 2017

\begin{abstract}
The microbiological quality of recreational waters (RW) has been assessed through the use of microbial indicators. Usually, three typical fecal bacteria, namely fecal coliforms, Escherichia coli and Enterococcus spp., are deemed by legislation and regulatory agencies for routine monitoring of the fecal contamination in RW. However, these traditional indicators have some limitations, as they underestimate health risks and do not determine the sources of contamination. Currently, the increasing concern with the minimization of human health risks associated with recreational water use and the protection of water resources outweigh the actual normative perspective. The potentials and limitations of conventional and alternative fecal contamination detection systems must be carefully evaluated, taking into account the specificities of each recreational water body and the natural or anthropogenic sources of environmental variability. The careful choice of analysis for detection and quantification of indicators in the light of their potential and shortcomings is of major importance for the timely evaluation of risks and implementation of strategies that effectively protect users and preserve water quality. This paper presents a critical literature review of the traditional and innovative methodologies for the analysis of fecal indicators in
\end{abstract}

Carla Rodrigues

carlar@esac.pt

Maria Ângela Cunha

acunha@ua.pt

1 Department of Exact Sciences, Higher School of Agriculture of Coimbra, Polytechnic Institute of Coimbra, 3040-316 Coimbra, Portugal

2 Department of Biology, University of Aveiro, Campus de Santiago, 3810-193 Aveiro, Portugal recreational water and intends to discuss their contribution for the management of the microbiological quality and safety of leisure surface waters.

Keywords Recreational water - Fecal indicators - Water quality $\cdot$ Water management

\section{Introduction}

The surface waters may be an important disease transmission vehicle due to the exposure of users to pathogenic organisms present in the water bodies. The health risk linked to the presence of these microorganisms depends on the pathogen form, type and concentration. A large variety of pathogenic forms may occur, including indigenous and external microorganisms, usually with considerable fecal content. The major cause of the presence of the pathogenic organisms in RW is anthropogenic activities, land use, and fecal pollution sources. Nevertheless, waterborne pathogenic organisms can occur ubiquitously in many aquatic habitats and humid soils. They are an important part of the biocoenosis in various substrates or water systems, especially in their preferred habitats, the biofilms.

Bacteria, protozoa and viruses, have been identified as the primary source of microbiological water contamination usually responsible for waterborne diseases (Russel and Walling 2007). However, additional groups, such as helminths worms and fungi, appear less frequently, specially at significant levels of contamination.

Routes of exposure to pathogens in RW are direct dermal contact, ingestion and inhalation resulting in adverse health effects (USEPA 2012). In addition to the public health aspects, the quality and safety of recreational inland and coastal waters is of utmost importance to bathers and 
other users, with a significant impact on the economy, particularly in tourist zones. Ensuring RW safety is a priority in the management of water resources, and a major concern for investors and economic operators. Moreover, the protection of these water bodies in the perspective of climate change and the urgent need for a wise management of ecological resources are priority stakes. This requires a strict program of surveillance of the microbiological quality of RW. Because of the biological diversity of pathogens, their power and infectious form, the intermittence of their appearance and low concentrations in water environment, and the lack of standardized methods for rapid analysis, their detection and quantification is difficult. Furthermore, the direct monitoring of a single pathogen can only provide specific information about it and does not allow gauging the presence of other potential contaminants (unless the degree of co-occurrence is established). Hence, although very promising techniques for pathogen analysis have been developed (Castillo et al. 2015), the assessment of RW safety monitoring still relies on the quantification of surrogate microorganisms, which are usually associated with fecal origin, being so-called fecal indicator bacteria (FIB). The FIB constitute a pathogen screening tool, that allows an easy cost-effective monitoring of the microbiological quality changes of water. Unfortunately, FIB monitoring is presently based on cultural methods that give results in 24-48 h, which hinders the provision of real-time information. This way, timely decisions could not be taken and the risk is raised. Hence, a great deal of research has been done so as to develop fast methods for both FIB quantification (Oliver et al. 2014), and the tracking of fecal contamination sources, desirably with the ability for online monitoring.

In this manuscript, we present an overview of several pathogen indicators and quantification methods to ensure the microbiological quality of RW. This article is structured into five sections. After this introduction, "Microbial pathogens in recreational waters" makes a brief survey of the presence and sources of pathogens in recreational waters. "Indicators and microbiological guidelines" is dedicated to the discussion between conventional and alternative microbial indicators as well as a comparative analysis of their advantages and constraints. "Methods for assessment of microbial water quality" explores the traditional and alternative methods for assessment of microbial water quality, especially in RW. In the same previous logic, we also present a comparative analysis between strengths and weaknesses of the available methods. Finally, "Conclusions and future perspectives" concludes the article by depicting the main drivers and constraints of indicators and methods for monitoring the microbiological content of RW.

\section{Microbial pathogens in recreational waters}

The deterioration of microbial quality of waters is related to the presence of microorganisms susceptible of causing infections or intoxications to users upon exposure. Some of the most common diseases are gastrointestinal illness, nausea and cramps, primary amoebae meningoencephalitis that leads to brain and meningeal inflammation, along with waterborne virus diseases, namely respiratory diseases, e.g., acute febrile respiratory illness, pneumonia, conjunctivitis. Other pathologies, e.g., typhoid fever, hepatitis, cholera, are less frequent (USEPA 2012). Examples of hazardous microbial forms of fecal origin found in contaminated beaches, streams and lake waters used for recreational activities are presented in Table 1.

Irrespective of their origin, microbial contamination loads may decay, persist or grow, depending on the microbial species and forms [e.g., vegetative cells, endospores, viruses, protozoan (oo)cysts], environmental conditions (e.g., UV irradiation, temperature, growth substrate availability, concentration of oxygen, transport characteristics, $\mathrm{pH}$, salinity) and the presence of other microorganisms (bacteria, viruses and predators). The interaction between biotic and abiotic factors, particularly climate factors, may contribute to the establishment of seasonal patterns of occurrence. Campylobacteriosis, salmonellosis, vero-cytotoxigenic and $E$. coli in temperate regions, are more frequent in summer and decrease in winter. Among the protozoan diseases, cryptosporidiosis has a well-defined seasonality (with spring and summer peaks) while giardiasis is less seasonal. Regional temperature and precipitation influence the persistence, transfer and proliferation of waterborne pathogens (Bouzid 2016). In temperate latitudes, during the colder months, the number of waterborne pathogens and associated indicators decrease, while in tropical climates, the warmest period favors the survival and re-inoculation of microbes in surface water (Pandey et al. 2012). Another factor is the impact of climate change on pathogenic behavior. Climate-induced trends (e.g., increased winter precipitation and extreme precipitation events during summer, increased runoff, increased duration and frequency of heat waves and heat extremes) affect the persistence and dispersal of waterborne pathogens in myriad ways, especially for environmentally ubiquitous and/or zoonotic microorganisms.

Pathogenic microorganisms are found among autochthonous communities (e.g., cyanobacteria, protozoa, vibrios) and are introduced into waters in various ways. These pathogens can be found in association with marine animals, phytoplankton, zooplankton, sediments and detritus (Cabral, 2010). Some infectious bacteria are indigenous to freshwater environments (Aeromonas 
Table 1 Examples of microbial pathogens occurring in contaminated recreational waters, sources and associated diseases

\begin{tabular}{|c|c|c|c|c|}
\hline Group & Microorganism & Common sources & Common pathways & Common disease \\
\hline \multirow[t]{10}{*}{ Bacteria } & $\begin{array}{l}\text { Salmonella spp. (e.g., S. enterica, } \\
\text { S. typhi) }\end{array}$ & $\begin{array}{l}\text { Humans and animals (pets, birds, } \\
\text { farm animals, wild life) }\end{array}$ & $\begin{array}{l}\text { Sewage, stormwater } \\
\text { runoff, agriculture, } \\
\text { beach sand }\end{array}$ & $\begin{array}{l}\text { Salmonellosis, gastroenteritis, } \\
\text { typhoid fever }\end{array}$ \\
\hline & $\begin{array}{l}\text { Escherichia coli } 0157: \mathrm{H} 7 \text { (and } \\
\text { serotypes O148, O124) }\end{array}$ & Cattle feces & $\begin{array}{l}\text { Sewage, surface runoff, } \\
\text { grazing cattle }\end{array}$ & Gastroenteritis, hemorrhagic diarrhea \\
\hline & Vibrio cholerae & Aquatic environment & Sewage & Cholera \\
\hline & Vibrio vulnificus & $\begin{array}{l}\text { Free-living inhabitants of brackish } \\
\text { water and salt water }\end{array}$ & $\begin{array}{l}\text { Estuarine, marine } \\
\text { environments }\end{array}$ & $\begin{array}{l}\text { Infections, gastroenteritis, } \\
\text { septicaemia }\end{array}$ \\
\hline & Legionella & $\begin{array}{l}\text { Biofilms in water systems, urine of } \\
\text { dogs, livestock, rodents, wild } \\
\text { animals }\end{array}$ & $\begin{array}{l}\text { Water environment, } \\
\text { runoff, sewage }\end{array}$ & Legionnaires' disease \\
\hline & Leptospira interrogans & $\begin{array}{l}\text { Urine and tissues of animals } \\
\text { (specially rats) }\end{array}$ & $\begin{array}{l}\text { Sewage, fresh water } \\
\text { accessible to animals }\end{array}$ & Leptospirosis (e.g., renal failure) \\
\hline & Shigella spp. & $\begin{array}{l}\text { Intestinal tract of humans and } \\
\text { animals }\end{array}$ & Urban sewerage & Bacillary dysentery or shigellosis \\
\hline & $\begin{array}{l}\text { Campylobacter spp. (e.g., } C . \\
\text { jejuni), Yersinia spp. (e.g., Y. } \\
\text { enterocolitica) }\end{array}$ & $\begin{array}{l}\text { Sewage, domestic, wild animal } \\
\text { feces, waterfowl feces }\end{array}$ & $\begin{array}{l}\text { Water environment, } \\
\text { beach sand and } \\
\text { sewerage outfalls }\end{array}$ & Gastroenteritis, campylobacteriosis \\
\hline & Klebsiella & Textile, pulp and paper mill wastes & $\begin{array}{l}\text { Urban and industrial } \\
\text { sewerage }\end{array}$ & Gastroenteritis \\
\hline & Clostridium perfringens & Feces of warm-blooded animals & $\begin{array}{l}\text { Urban sewerage, runoff, } \\
\text { sewerage outfalls } \\
\text { sediments }\end{array}$ & $\begin{array}{l}\text { Stomach, respiratory, skin, brain and } \\
\text { nerve effects }\end{array}$ \\
\hline \multirow[t]{4}{*}{$\begin{array}{r}\text { Emerging } \\
\text { bacteria }\end{array}$} & Mycobacterium avium Complex & Water environment & $\begin{array}{l}\text { Water environment, soil, } \\
\text { piped water supply, } \\
\text { house dust }\end{array}$ & $\begin{array}{l}\text { Respiratory or the gastrointestinal } \\
\text { tract }\end{array}$ \\
\hline & Helicobacter pylori & Humans & $\begin{array}{l}\text { drinking water biofilms, } \\
\text { sewage }\end{array}$ & $\begin{array}{l}\text { Gastroenteritis, duodenal ulcer } \\
\text { disease and gastric carcinoma }\end{array}$ \\
\hline & Aeromonas hydrophila & Human feces & Water sources & $\begin{array}{l}\text { Gastroenteritis, septicemia, } \\
\text { meningitis, wound, infections }\end{array}$ \\
\hline & Plesiomonas shigelloides & $\begin{array}{l}\text { Feces of warm-blooded animals, } \\
\text { aquatic environment }\end{array}$ & Sewage & Gastroenteritis, diarrhoeal cases \\
\hline \multirow[t]{5}{*}{ Viruses } & Enteroviruses & Human feces & Sewage, septic tanks & $\begin{array}{l}\text { Gastroenteritis, heart anomalies, } \\
\text { meningitis, diarrhea }\end{array}$ \\
\hline & Hepatitis A, Hepatitis $\mathrm{E}^{2}$ & $\begin{array}{l}\text { Humans feces, humans feces, pigs } \\
\text { feces }\end{array}$ & $\begin{array}{l}\text { Human sewage, } \\
\text { agricultural sewage }\end{array}$ & Infectious hepatitis \\
\hline & Adenovirus & Humans feces & Sewage & $\begin{array}{l}\text { Respiratory, urinary disease, } \\
\text { gastroenteritis }\end{array}$ \\
\hline & Rotaviruses (Rotavirus) & Human feces & Sewage & Gastroenteritis, diarrhea \\
\hline & $\begin{array}{l}\text { Norovirus (previously Norwalk } \\
\text { like viruses) }\end{array}$ & $\begin{array}{l}\text { Stool or vomit of infected } \\
\text { individual patients }\end{array}$ & Sewage & Gastroenteritis \\
\hline \multirow[t]{5}{*}{ Protozoa } & Cryptosporidium oocysts & $\begin{array}{l}\text { Human, animal and bird feces (e.g., } \\
\text { Peking ducks, neonate animals }\end{array}$ & $\begin{array}{l}\text { Sewage, stormwater } \\
\text { runoff }\end{array}$ & $\begin{array}{l}\text { Cryptosporidiosis, cholecystitis, } \\
\text { hepatitis, respiratory disease, } \\
\text { reactive arthritis }\end{array}$ \\
\hline & Acanthamoeba castellanii & $\begin{array}{l}\text { Free-living amoeba, environment } \\
\text { (they feed on bacteria, fungi, } \\
\text { cyanobacteria) }\end{array}$ & $\begin{array}{l}\text { Sewage, disposal waste at } \\
\text { sea, marine sediments }\end{array}$ & $\begin{array}{l}\text { Acanthamoeba keratitis, } \\
\text { granulomatous amoebic } \\
\text { encephalitis }\end{array}$ \\
\hline & $\begin{array}{l}\text { Microsporidia } \\
\text { Encephalitozoonidae }\end{array}$ & $\begin{array}{l}\text { Livestock, fowl pets, rabbits, mice, } \\
\text { pigs, cows, goats }\end{array}$ & $\begin{array}{l}\text { Environmental sources of } \\
\text { microsporidia }\end{array}$ & $\begin{array}{l}\text { Gastrointestinal disease, infections of } \\
\text { the reproductive, respiratory, } \\
\text { nervous tissue }\end{array}$ \\
\hline & Naegleria fowleri & Bird, aquatic mammal feces & Water environment & $\begin{array}{l}\text { Primary amoebae } \\
\text { meningoencephalitis }\end{array}$ \\
\hline & Giardia lamblia (cysts) & $\begin{array}{l}\text { Human, domestic and wild animal } \\
\text { feces, bird feces }\end{array}$ & $\begin{array}{l}\text { Sewage, stormwater } \\
\text { runoff }\end{array}$ & Giardiasis, abdominal cramps \\
\hline
\end{tabular}

Adapted from: Pond (2005); Health Canada (2006); Russel and Walling (2007); Ogden et al. (2009); Cabral (2010); Dorevitch et al. (2012) and Oliver (2015) 
hydrophila, Naegleria fowleri, Legionella pneumophila) and to marine and brackish waters (e.g., Vibrio cholerae and other vibrios, Aeromonas spp.). Sediments, submerged aquatic vegetation and other aquatic organisms like protozoa (e.g., amoebae) may be natural reservoirs of many types of pathogens (Pandey et al. 2012). Beach sand and soil on the banks of rivers, lakes, ponds or estuaries are also significant sources of biological contaminants (e.g., Campylobacter spp., Cryptosporidium and Giardia cysts, Aspergillus sp., Trichophyton sp. and Microsporum sp. (Whitman et al. 2014). Fecal pollution of beach sand may be directly caused by animal droppings or developed as an indirect result of inundation with contaminated water from an adjacent river lake or sea. Pathogens may persist and/or re-grow in beach sand driven by periodic wetting through wave heights and tides and the concentration of fecal indicators in sand may be even greater than that observed in RW (Halliday and Gast 2011). Soils are also a relevant source of pathogens and may have concentrations of microorganisms up to 100 -fold higher than in nearby waters (Sabino et al. 2014). The pathogens can be deposited on the land surface and subsequently conveyed to the stream during and after rainfall events achieving the RW (Ogden et al. 2009). Although pathogenic microorganisms may be found among natural aquatic bacterial communities, pathogens occurring in RW also emanate from contamination with fecal material transported by untreated or deficiently treated discharge and runoff waters. Environmental sources of pathogens include urban, slaughterhouse and animal husbandry wastewaters, sewer overflows, especially during heavy rainfall periods, human fecal discharge from boats and feces of waterfowl (e.g., gulls and geese). Runoff waters from agricultural land treated with manure or used for livestock grazing or penning and leaking septic tanks are also sources of microbial pathogens.

Due to the variety of pathogen sources and their impacts in terms of public health, it is important to trace the origin of microbial contamination. Microbial source tracking (MST), which includes many decision-making steps and refers to a group of analytical protocols to trace the origin of fecal contamination, is currently a valuable tool for the management and mitigation of this form of pollution.

\section{Indicators and microbiological guidelines}

The number of hazardous microorganisms and the diversity of forms and physiological conditions where they occur as water contaminants makes analytical procedures of detection and quantification complex, laborious and costly. Also, the scarcity of necessary skills and equipment in laboratories may hinder the routine analyses of pathogens in water. Many pathogens are not easily detected, because they occur in very small numbers and are difficult to culture (Harwood et al. 2014). Hence, vegetative cells and endospores of bacteria that are numerous in the feces of humans and warm-blooded animals are commonly used as sentinel and interpreted as indicators of elevated pathogenic risk. Because of inherent difficulties within the process of pathogen detection and quantification, microbiological water quality assessment is made by the evaluation of microorganism indicators. In the context of RW assessment, an indicator is a surrogate used to demonstrate or predict water bodies' vulnerability to contamination, and/or the potential for public health risk outcomes. The commonly used indicators are FIB, which are used to estimate the potential presence or absence of hardto-detect target pathogenic organisms surviving under similar physical, chemical, and nutrient conditions. The ideal fecal indicator should include each one of the following criteria: it cannot be able to multiply outside the intestinal tract; its, survival, decay and transport rate in the extra-enteric environments should be similar to pathogens; its density should be directly correlated with the degree of fecal contamination and public health risk; it should be interpreted as a surrogate for many different pathogens and it should be affordable to analyze with basic equipment requirements (Ferguson and Signoretto 2011).

While the use of FIB to assess the microbiological quality of RW safety is consensual, there is not a universal agreement on which indicator organisms are most useful. Systems of indicators have evolved in time and are still debatable.

\section{Conventional indicators of fecal contamination}

The classical indicators commonly used in assessing the fecal contamination of RW are the coliform group (total coliforms, fecal coliforms, E. coli); streptococci (enterococci, fecal streptococci) and spore formers (Clostridium perfringens). The study of these indicators is made by defining levels of risk in relation to the total spectrum of waterborne pathogens; i.e., the presence of bacterial, viral and protozoan pathogens. Table 2 summarizes the compliance of traditional fecal indicators with the main criteria for the selection of indicator microorganisms.

Coliforms belong to a single taxonomic family of Enterobacteriaceae. They are capable of aerobic and facultative anaerobic growth. They ferment lactose with gas production at $35^{\circ} \mathrm{C}$ within $48 \mathrm{~h}$ and are $\beta$-galactosidase positive (Lebaron et al. 2005). While some members of the coliform group are common in the intestinal tract of mammals and birds (e.g., E. coli), others occur in soil and on the surface of plants (e.g., Klebsiella, Enterobacter aerogenes, Enterobacter cloacae) and are not directly 
Table 2 Criteria for selecting a microorganism as an indicator (adapted from Payment et al. 2010)

\begin{tabular}{llllll}
\hline Parameter & Microorganism & & & \\
\cline { 2 - 5 } & Escherichia coli & Enterococci & C. perfringens & Somatic coliphages & Male specific \\
\hline Associated with pathogen & Yes & Yes & Yes & Yes/no & Yes \\
Associated with fecal contamination & High & Medium & High & ISD & High \\
Number in source water & High & High & Low & High & Medium \\
Survival in the environment & Medium & High/medium & Very high & No & High \\
Resistance to treatment & Low & Low; ISD & Very high & Medium \\
Pathogenic & Yes/no & Yes/no & Yes/no & Medium \\
Cost & Medium/low & Medium/low & Medium/low & No \\
Risk to analyst & Medium & Medium & Low & Medium & Medium \\
Enumeration & Easy & Easy & Easy & Medium \\
Speed of measurement & Medium & Medium & Medium & Medium \\
Technical difficulty & Medium & Medium & Medium & Medium & Medium \\
\hline
\end{tabular}

associated with fecal contamination. Hence, the coliform group represents not only the intestinal bacteria, but also other free-living (non-fecal) coliforms. Much of the doubtful situations where coliform measurements cannot always be linked to the input of fecal wastes can be avoided by using fecal coliforms (FC) as indicators. The term FC was originally used to identify a subset of the coliform group of a purely fecal origin, distinguishable by their capacity to grow at $44.5{ }^{\circ} \mathrm{C}$. However, free-living environmental FC may occur. Therefore, these organisms are not absolutely reliable as FIB (Wade et al. 2006). So, the FC is replaced by thermo-tolerant coliforms (TC) because they are more closely linked to fecal contamination. The TC are coliforms resistant to high temperatures, able to grow and ferment lactose with the production of gas at $44{ }^{\circ} \mathrm{C}$ within $24 \mathrm{~h}$ and includes thermo-tolerant strains of Klebsiella spp., Enterobacter spp. and Citrobacter spp. However, some TC species (e.g., genus Klebsiella derived from pulp and paper mill effluents) have been isolated from environmental samples in the apparent absence of fecal contamination. Typically, E. coli is the main bacterium within the majority of the TC. It is characterized by indole production from tryptophan. It is also enzymatically distinguished by the lack of urease and the presence of $\beta$ glucuronidase. As part of the natural and commensal inhabitants of the normal gut microbiota, most of E. coli strains are innocuous, but a small portion of them are pathogenic. Because E. coli is consistently found in human, farm animal and pet feces with a much higher abundance than other coliforms, this bacterium has been regarded as the only coliform almost exclusively associated with a fecal source (WHO 2012). The significant association between $E$. coli and gastrointestinal illness (Wu et al. 2011), survival rates similar to many fecal bacterial pathogens (Cook and Bolster 2007) and the availability of affordable, fast, sensitive, specific and easy detection methods for E. coli (Wade et al. 2006) justifies a replacement of the TC by $E$. coli in indicator systems.

In addition, other indicators such as the intestinal enterococci and Clostridium perfringens spores and (or) vegetative cells, have also been used over the time and can be helpful when used in combination with coliforms, like E. coli. Intestinal enterococci are a subgroup of organisms defined as fecal streptococci. These are a taxonomically heterogeneous cocci set associated with the gastrointestinal tract of humans and warm-blooded animals, and are represented by various species from the genus Streptococcus (e.g., Streptococcus bovis and S. equinus) and genus Enterococcus (e.g., Enterococcus faecalis, E. faecium, E. durans, E. hirae, E. cecorum). Initially classified in the genus Streptococcus, the enterococci are distinguished by their ability to grow at temperatures ranging from 10 to $45{ }^{\circ} \mathrm{C}$ in $6.5 \% \mathrm{NaCl}$ at $\mathrm{pH} 9.6$, survive at $60{ }^{\circ} \mathrm{C}$ for $30 \mathrm{~min}$, reduce $0.1 \%$ methylene blue and give a positive reaction with Lancefield's Group D antisera. They also express the enzyme $\beta$-glucosidase. In 1984, enterococci were given formal genus status, after genetic (DNA-DNA and DNA - RNA hybridization) studies demonstrated a more distant relationship with the streptococci. The Enterococcus was proposed as a unique genus, separate from Streptococcus (Byappanahalli et al. 2012). According to ISO 7899-2, intestinal enterococci are able to reduce 2,3,5triphenyltetrazolium chloride to formazan and to hydrolyse esculin at $44{ }^{\circ} \mathrm{C}$ on the selective media, Slanetz and Bartley agar, containing sodium azide, which inhibits the growth of Gram-negative and staphylococci. Intestinal enterococci are typically found in the intestinal tract and feces of humans and animals, and some data suggest that $E$. faecium and $E$. faecalis may be more prevalent in human feces than other enterococcal species (Boehm and 
Sassoubre 2014). However, some members of the intestinal enterococci have also been detected in soil in the absence of fecal contamination, and occasionally from other habitats (Health Canada 2012). Intestinal enterococci are able to survive under a wide range of environmental conditions including extremes of temperature and salt concentration and due to their ubiquity in human feces and persistence in the environment. They may better mimic the fate and dispersion of the most resistant pathogens, such as viruses (Wade et al. 2006). Thus, they are currently considered as the most informative indicators in the microbiological monitoring of marine RW. Nonetheless, debate is now starting to be raised about the use of intestinal enterococci as FIB (Boehm and Sassoubre 2014).

Clostridium perfringens is the species of clostridia, spore-forming bacteria, associated with the feces of humans and warm-blooded animals. Spores of $C$. perfringens can generally persist longer in water than nonsporeforming bacteria such as coliforms (Wade et al. 2006). It has been considered that this anaerobe is a useful indicator of past pollution and a good tracer to follow the fate of pathogens, especially parasitic protozoan and enteric viruses (Health Canada 2012). C. perfringens is a better indicator for certain pathogenic protozoa than $E$. coli (Field and Samadpour 2007). It is also used as an alternative FIB in tropical and subtropical waters because other indicator bacteria may regrow in these environments (Ferguson and Signoretto 2011). Furthermore, the resistance of bacterial spores can make the $C$. perfringens an interesting indicator of fecal contamination in waters receiving toxic industrial wastes that rapidly inactivate other bacterial indicators. On the other hand, $C$. perfringens may be present at concentrations mistakenly considered to be indicative of a health risk long after the pathogens have declined to acceptable levels. Exceptionally, the long survival of $C$. perfringens in the water environment creates a residual population of this organism, which can obscure the detection of low densities of recent polluting discharges to the receiving waters.

\section{Quality guidelines based on FIB}

The indicator systems based on national standards or guidelines for the microbiological quality of RW in countries such as Australia, the USA and European Union have considerably changed in terms of FIB. For more than one hundred years, bacteria of the coliform group (total coliforms), the FC thermo-tolerant members of the coliform group, intestinal enterococci and vegetative cells and endospores of clostridia have been used as FIB (Savichtcheva and Okabe 2006). Before the 1980s, the microbial standard most commonly used in the USA and Europe was based on total and fecal coliforms. Total coliforms were rejected because they are not specific for fecal contamination, and were not regarded as good indicators of vulnerability to waterborne hazard. Instead, the more fecal-specific FC were considered to provide a more realistic estimate of the health hazard. The United States Environmental Protection Agency and the National Technical Advisory Committee recommended the sole use of FC as FIB to evaluate the microbiological quality of RW. Later, the TC designation started to be used, although they also include organisms whose source is not exclusively fecal, weakening their reliability as FIB. Actually, E. coli is the only member of (thermo-tolerant) coliforms that, together with (intestinal) enterococci, satisfies most of the criteria for an ideal FIB. Multiple studies have shown that E. coli and enterococci correlate better with disease outbreaks than other classical indicators (Byappanahalli et al. 2012) and are regarded as the best candidates to primary and mandatory fecal indicators in RW (Wu et al. 2011; USEPA 2012). The definition of FIB risk analysis, the results of epidemiological studies, the correlation between FIB and the occurrence of pathogens and the reflections of the scientific-technical community have lead United States Environmental Protection Agency (USEPA) to recommend the use of $E$. coli and enterococci as FIB to RW (USEPA, 1986). This was followed by the Canadian Authorities (CCREM 1991) as well as the International Organization for Standardization (ISO 1998a, b). Following the EPA Clean Water Act $\$ 304$ recommendations, several states in the USA adopted $E$. coli or intestinal enterococci concentrations as criteria for the hazards to human health (USEPA 2012). These FIB were also recommended by World Health Organization (WHO) and adopted by the Australian and New Zealand Environment Conservation Council (ANZECC 2000) and European Union RW guidelines as water-quality indicators for RW. In the European Bathing Water Directive (Directive 2006/7/EC of 15.02), EU removed total coliforms as FIB from legislation, and replaced FC and fecal streptococci by $E$. coli and intestinal enterococci, respectively. Despite the major objective of analyzing FIB is to infer the risk associated to the presence of pathogens and consequently, of the possible public health hazard, the conventional FIB are unable to predict, under certain conditions, public health risks (Dorevitch et al. 2012). The performance of the traditional FIB as surrogates has not been sufficient to ensure microbiological safety of RW due to its intrinsic limitations.

\section{Limitations of FIB-based guidelines}

Because of the exclusive reliance of current legislation on FIB, monitoring has focused only on these microorganisms and lost sight of pathogens. Although an indicator should be correlated with the presence of pathogens and have a 
similar survival profile to the ones it detects, sometimes the FIB concentrations are not always correlated with the concentration of pathogens. Some studies have demonstrated a low or absent correlation with the presence of pathogenic forms, e.g., protozoan parasites and enteric viruses, virions, endospores, (oo)cysts (Wu et al. 2011), and a variable degree of correlation with viral and zoonotic pathogens (Ahmed et al. 2010). This issue is generally attributed to the widely differing physiology, phylogeny and ecology of FIB and pathogens. For example, E. coli and enterococci are not well correlated with pathogenic Cryptosporidium and Giardia spp. (Lemarchand and Lebaron 2003; Harwood et al. 2005), Salmonella spp. (Lemarchand and Lebaron 2003), Campylobacter spp. and human enteroviruses (Lemarchand and Lebaron 2003; Hellein et al. 2011). In addition, conventional FIB also have drawbacks including faster death than viral pathogens in water, and growth outside the animal host. E. coli and enterococci survive and grow in natural environments, such as fresh water lakes and streams, algal wrack (Byappanahalli et al. 2003), beach sand, soils and sediments (Whitman et al. 2014). Also, the FIB cannot identify the source of contamination (point vs non-point source; human vs animal). Another constraint associated with FIB-based guidelines is the low amenability for sensor detection and real-time monitoring limitation, which hinder early-warnings and the timely implementation of measures to control or mitigate contaminations and protect public health (e.g., interdiction of beach). The absence of such measures might cause loss of valuable recreation access and disrupt local tourism-dependent businesses (WHO 2012). Another issue that is currently under discussion is associated with the impacts of the potential effects of climate change on the FBI. It is widely accepted that the climate change conditions have been associated with a modification of FIB prevalence and dispersion. Exposure routes and the risks posed by RW-borne pathogens to future communities may be very different than those posed today (Bouzid 2016). Increased surface water temperature is expected to alter environmental conditions within an aquatic ecosystem (e.g., promoting phytoplankton biomass, increasing levels of sediments and dissolved organic carbon in water column), and to result in generally higher microbial activity as well as changes in the pathogenic community composition (Coffey et al. 2014). Despite major concern about how climate changes will alter the dynamics of aquatic ecosystem, predictions about certain bacterial and protozoa productivity can be made, namely which ones exhibit higher growth rates with increasing temperature (e.g., Clostridium botulinum, Campylobacter and Vibrio cholera (Ogden et al. 2009; Cabral 2010)). Special attention should be given to viral community associated with RW, namely the human adenovirus, hepatitis $\mathrm{A}$ and $\mathrm{E}$, dengue virus which can pose risk to public health in the future (Bouzid 2016). Similarly, combined changes in rainfall, temperature, and human land use will have important impacts on FIB behavior. Increased cases of waterborne diseases due to urban flooding with association of erosion, sediment transport and rural and suburban drainage, with a high concentration of pathogenic organisms, may be the other important health consequences of climate change. Efforts to accurately model extreme weather conditions (i.e., precipitation and temperature) may be further complex as a result of uncertainty in simulating the re-suspension of bacteria in sediment and bacteria decay/growth in the environment (Coffey et al. 2014). The high erosion rates, driven by climate change, will further increase the development of sediment deposition and resuspension zones along with potential reservoirs for FIB. Although the exact nature and magnitude of the effects of climate change on recreational water and public health risk remains ambiguous, they could exacerbate waterborne pathogenic problems (Coffey et al. 2014). So, the efforts to decide upon the appropriate surrogates used to ensure RW safety in a climate change scenario are deemed vital.

With previously mentioned conditions and the need to think beyond legislation, rapid methods for the analysis have been proposed, and alternative indicators of fecal contamination have been considered.

\section{Alternative microbial indicators}

To address the limitations of traditional FIB, the screening of unconventional microbes has been proposed as a way of finding more suitable indicators of microbiological water quality. Fecal anaerobes, especially Bacteroides spp., Bifidobacterium spp. and bacteriophages have been addressed as potential FIB or viruses. Some studies also focused on Firmicutes (McLellan et al. 2013), Methanobrevibacter smithii, a common anaerobic archaeon in the intestine was found in sewage (Johnston et al. 2010), and human polyomavirus (Hellein et al. 2011). Fecal anaerobes may be more indicative of the presence of pathogens because they are unlikely to grow once released from their host into the environment. Bacteroides have long been considered a candidate indicator of fecal contamination, because they are among the dominant bacterial groups in the human gut (Wade et al. 2006) and consequently their high occurrence in human feces can reach concentrations outnumbering E. coli concentrations by as much as 100 - to 1000 -fold (Health Canada 2012). Also, due to their inability to grow in the environment, they are expected to persist for much shorter periods than conventional FIB and their concentrations in animal scat are 2-5 orders of magnitude lower than human feces (Converse et al. 2009). Bacteroides spp., are Gram-negative, obligate anaerobic bacteria, whose 
dominant species are B. fragilis, B. vulgatus, B. distasonis and B. thetaiotaomicron. Detection of Bacteroides genetic markers in RW is a relatively new area of research, but molecular markers have been developed for the genus that are generally more concentrated in human fecal material than animal (Converse et al. 2009), and have been shown to be sensitive markers of human sewage in microbial sourcetracking efforts (Harwood et al. 2014). The research undertaken to date suggests that Bacteroides markers may have a stronger role as a secondary indicator of fecal contamination, providing information on the potential sources of fecal material (Health Canada 2012).

The genus Bifidobacterium is Gram-positive, obligate anaerobe and represents the third most abundant bacterial population in the human intestine, after Bacteroides and Eubacterium (Health Canada 2012). Bifidobacterium species are exclusively of fecal origin and some of them occur in human feces more than E. coli. Moreover, they were also frequently detected in cases of little difference in the concentrations of FC, enterococci, or clostridia between human and animal fecal contamination. Therefore, unlike conventional FIB, Bifidobacterium spp. might be used to discriminate the origin of fecal pollution, even in tropical freshwaters (Savichtcheva and Okabe 2006). Due to their physiology and complex growth requirements, Bifidobacterium spp. are unlikely to grow in water, in contrast with E. coli. Despite the advantages of Bifidobacterium spp. to act as potential indicators of fecal contamination in RW, there is still a gap in current knowledge on their extraenteric behavior and persistence in water environments (Savichtcheva and Okabe 2006).

Bacteriophages, or simply phages are viruses that infect bacteria. They might be appropriate biological entities to predict the behavior of enteric viruses in water environments. Despite their role in the assessment of microbiological quality of RW, there is no consensus on the suitable group of bacteriophages to be used. However, somatic coliphages, F (male)-specific RNA bacteriophages (FRNA phages), and phages of Bacteroides fragilis have been proposed as model virus indicators of fecal contamination and biotracers of contamination sources. They are thought to more closely resemble enteric viruses because of their morphology and survival characteristics, environmental persistence and resistance to disinfection, as compared with the traditional FIB (Health Canada 2012). Commonly, the amount of phages is ten times higher than that of enteroviruses in environmental water samples (Savichtcheva and Okabe 2006). However, enteric viruses have been detected in water environments in the absence of somatic coliphages, and some of them may replicate in water environments (Health Canada 2012). Male-specific $\left(\mathrm{F}^{+}\right)$coliphages (include $\mathrm{F}^{+}$RNA phages and $\mathrm{F}^{+}$DNA phages) have a greater specificity than somatic coliphages.
Some studies demonstrated a better correlation of these with infectious enteroviruses and enteric viruses than somatic phages (Health Canada 2012; USEPA 2012) and significant correlations with adenoviruses in environmental waters (Wu et al. 2011), although their presence does not always correlate with the occurrence of human enteric viruses (Hot et al. 2003). Despite the interesting physical (size and shape) resemblance of $\mathrm{F}^{+}$RNA phages to human viruses, and their significance in sewage and wastewater, their value as reliable indicators of fecal contamination (enteric viruses) is still controversial (Health Canada 2012). Therefore, $\mathrm{F}^{+}$RNA phages may be more useful as a surrogate of potential pathogen than a primary indicator of fecal contamination.

Bacteriophages of Bacteroides fragilis are viruses that infect $B$. fragilis. Nevertheless, the concentration of $B$. fragilis phages, isolated from sewage, have been shown to be lower than that of $B$. fragilis and also lower than somatic coliphages and then F-specific RNA bacteriophages. However, phages of $B$. fragilis might combine some desirable properties from both the coliphage group and Bacteroides spp. Their survival in extra-enteric environments is comparable (or better) than enteric viruses (Llivina et al. 2005). They also seem to be the most persistent of the phage indicators (WHO 2003). Their inability to grow in the environment, the structural similarities to the enteric viruses and their specificity for indicator of human fecal contamination (e.g., B. fragilis HSP 40 strain) are potential useful properties to make phages of $B$. fragilis a possible alternative surrogate.

\section{Combined systems of indicators}

In general, none of the organisms discussed previously can be used as a universal indicator nor can they overcome all limitations of standard FIB in assessing microbial safety of $\mathrm{RW}$. There is a general consensus around the idea that public health is not adequately protected based only on the detection of a single indicator and requires the combined monitoring of alternative indicators along with the conventional ones. It may also be recommended that this set include indicators of recent and old contaminations. The question lies in defining the set of indicators, allowing the most suitable approach to safety of microbiological RW quality. Few studies have been conducted on establishing a correlation between (enteric) pathogens with FIB, and therefore providing some guidance in identifying potential alternative indicators of fecal contamination. $\mathrm{Wu}$ et al. (2011) concluded that, among the indicators analyzed, the F-specific coliphages are better indicators for viral pathogens while $C$. perfringens are likely to be useful indicators for the group of pathogens covered herein (Salmonella, Cryptosporidium, Giardia, adenoviruses, Enteroviruses). 
E. coli and enterococci do not correlate better with pathogens than other indicators, but their detection in water is generally interpreted as indicative of fecal contamination. As the coliphages frequently correlate with viral pathogens (namely adenovirus), the inclusion of this indicator has also been proposed.

A brief description of traditional indicators and some new potential microbial indicators for RW contamination is given in Table 3.

\section{Methods for assessment of microbial water quality}

Traditionally, RW have been routinely assessed for FIB by culture-based conventional methods. However, the long time required for delivery of accurate results, the intrinsic low sensitivity, the lack of specificity and reliability and inability to indicate the source of contamination of these methods have been widely pointed as important drawbacks. A set of alternative microbiological methods has been proposed which can fall into two main groups: molecular and enzymatic methods. Also, some approaches are solely based on a single technique, whereas other strategies take advantage of the combination of different methods. A brief description of commonly available methods for assessment of microbial RW quality is made below.

\section{Conventional methods}

The classical techniques are based on metabolic reactions or growth response after a suitable incubation period in an appropriate substrate. These methods are generally accepted in FIB routine analyses that mainly include multiple tube fermentation (MTF) and membrane filter (MF).

In the MTF procedure/most probable number (MPN) procedure, tenfold dilutions of the water are added to tubes containing the appropriate medium, incubated and then followed up through the additional confirmation steps. The results of this procedure are only a statistical estimate of the number of bacteria that does not give an accurate count of their actual number.

By incorporating synthetic substrates for marker enzymes (chromogen, fluorogen or a combination of both) in the broth medium, the traditional methods can be made to a specific group, genus or species and might reduce the analysis time. It is possible to save time through these methods because the target organisms are characterized by a specific enzyme that, after the substrate hydrolysis, releases to the media a color or a fluorophore product. In membrane filter (MF) procedure, the water sample is filtered and the filter is then placed on a standard presumptive bacteria solid medium which requires additional steps to confirm their presence, or on a medium containing synthetic enzyme-substrates for the specific detection and confirmation in a single step of target organisms before incubation. In this approach, the isolated discrete colonies of bacteria exhibit fluorescence under UV light or change color due to the action of the enzyme.

These methods can be easily adapted to any analytical capacities of the site. They are relatively cheap, very easy to use and require no complex equipment. Moreover, there are currently several accredited methods providing a standardized protocol that facilitates comparison amongst different laboratories. On the other hand, they require at least $24 \mathrm{~h}$ before a result can be obtained. These methods are non-specific, so it is difficult to identify the source of contamination (human or animal) or even if the bacteria are actually from fecal matter and not a native soil population (Byappanahalli et al. 2012). The other disadvantage of conventional cultivation-based methods is a weak level of detection of slow-growing or stressed cells, i.e., cells in a "viable-but-not-culturable" state (VBNC), causing strong underestimations when compared with the number of intact cells.

\section{Alternative methods}

Alternatively, molecular and enzymatic methods have been developed to overcome the less favorable aspects of conventional ones. In the molecular methods, the objective is to label the target microorganism by binding it to molecular structures on the exterior surface or to structures within the interior of a cell. The first ones can be classified as immunological methods, and the others as nucleic acid methods. The range of these available methods has increased, because they are able to achieve a high degree of sensitivity and specificity Also, they are adaptable to a wider set of indicators and pathogens at a low costs (Gilbride, 2014). However, they may not distinguish live from dead bacteria and they require extensive training and highly specialized equipment.

\section{Immunological methods}

Immunological methods are based on the specificity of the antigen-antibody complex and the high affinity that is a characteristic of this recognition reaction. Common use of the antigen-antibody binding reactions includes cell capture by enzyme-linked immunosorbent assay (ELISA), immunomagnetic assays (IMS), or targeted cell detection through immunofluorescence assay (IFA) or immuno-enzyme assay (IEA). The enzyme-linked fluorescent immunoassay is a cellular component-based technology that tags an antibody with an enzyme. Antibodies can be raised and conjugated to enzymes that catalyze the breakdown of chromogenic or fluorogenic substrates. After 
Table 3 Strengths and weaknesses of classical and alternative microbial indicator organisms

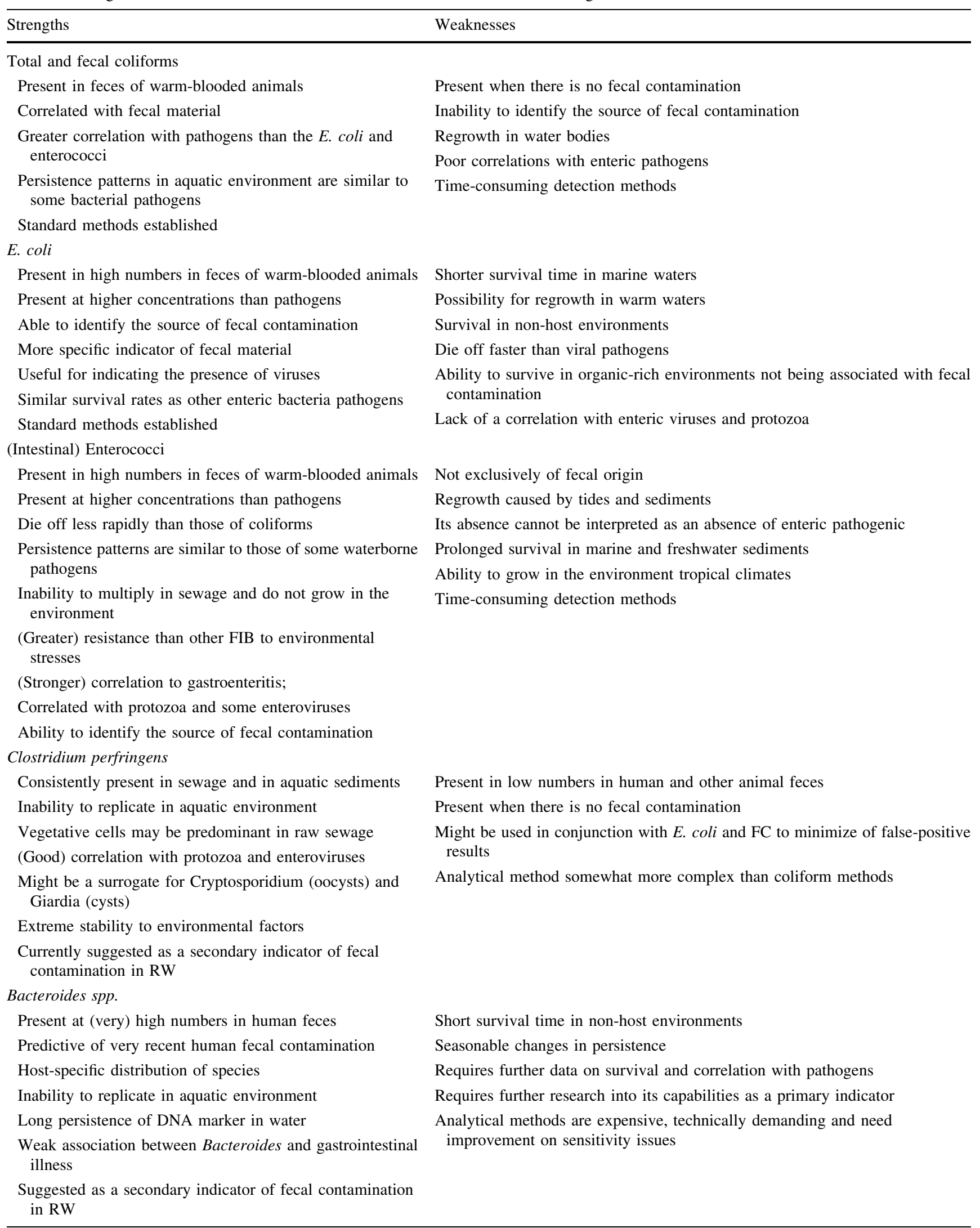


Table 3 continued

\begin{tabular}{ll}
\hline Strengths & Weaknesses \\
\hline Bifidobacterium spp. & \\
Present at high numbers in the gut of humans & Relatively short survival time \\
Rarely found in animals & Low frequency of detection and recovery from warm waters \\
Exclusively of fecal origin & Inhibition of the recovery due to background bacteria \\
Host-specific distribution of species & Requires further data on survival and correlation with pathogens and in its \\
Survival characteristics are similar to those of $E$. coli & capabilities as an primary indicator \\
Inability to survive in the extra-enteric environments & Needs improvement on specificity and sensitivity of detect
\end{tabular}

Genetic marker of human fecal contamination

Adapted from: Harwood et al. (2005); Savichtcheva and Okabe (2006); Wade et al. (2006); Field and Samadpour (2007); Wu et al. (2011); Byappanahalli et al. (2012) and Health Canada (2012)

incubation, an enzyme substrate is added. The formation of a pigmented product is indicative of the amount of enzymes present in the sample, and the amount of microorganism is obtained. Assay times vary from 24 to $52 \mathrm{~h}$ for bacteria and enrichment may be necessary to ensure detection (Zourob et al. 2008). Various easy-to-use commercial ELISA kits are available, especially for clinical and food application (such as the Wellcolex kits, VIDAS and Mini-VIDAS), but availability and research for environmental water application is needed. In IFA assay, the antibodies are tagged with a dye that fluoresces under UV light. The enumeration can be accomplished by epifluorescent microscopy or solid-phase cytometry after filtration of the water sample, or even by flow cytometry. Enumeration of positive reactions provides a measurement of population size. Despite the usage of IFA in the environment water namely for the evaluation of fecal contamination in samples from coastal and lake waters (Caruso et al. 2000, 2002), there is still a continuing need for further research in this field. An example of a commercially available instrument is Chem Scan ${ }^{\circledR}$, which can detect and enumerate fluorescent bacteria.

\section{Nucleic acid-based methods}

Nucleic acid methods have the ability to detect nucleic acids such as DNA or RNA, by introduction of a probe, and to allow the characterization of bacteria by genotype, rather than by phenotype and thus require the identification of a unique genetic signature for individual or groups of microorganism strains. The probes can be labeled with a radioisotope, an enzyme, a fluorescent or a chromogen. The most commonly used hybridization strategies are fluorescence in situ hybridization (FISH) and the polymerase chain reaction (PCR). In the FISH technique, primarily oligonucleotide probes (short probes) are used to detect complementary nucleic acid sequences within intact cells. After processing the sample and if the target microorganism is present, the reaction results in the microorganism "glowing". Then, after hybridization and following the post-hybridization washing, the specifically stained cells are usually detected by epifluorescence microscopy. FISH is currently considered as a highly specific cellular detection method, namely in water environments, and relatively easy to perform (Roldan et al. 2013). FISH has been used to detect viable $E$. coli in river water (Garcia-Armisen and Servais 2004). Nevertheless, the specificity of detection depends on the specificity of the oligonucleotidic probe and on the stringency of hybridization conditions being used. Thus, for a given probe, excessive numbers of non-target bacteria may give false-positive results. A number of FISH methods have been developed and used for the detection of FIB, but the main shortcoming of this technique lies in the lack of commercial availability of probes targeting the desired bacterial taxon or group (Roldan et al. 2013). Various commercial kits of FISH are available, such as Label IT ${ }^{\circledR}$ Fluorescence In Situ Hybridization Kit $\mathrm{Cy}^{\circledR} 3$, fluorescein and TM-Rhodamine.

Nucleic acid amplification technology based on PCR reactions is a genotype technology and operates like a "photocopier machine": making copies of nucleic acid fragments (DNA or RNA), within several hours. These are amplified using polymerization techniques as used in the cell, i.e., a mirror-image copy is made and then used to make subsequent copies of the original target. The results of PCR can be detected by fluorescent double-strand DNA dyes or probes (Roldan et al. 2013). Several modifications of the PCR technique have been presented to increase accuracy with a variety of PCR methods, such as quantitative PCR, qPCR (combining the specificity of conventional PCR with the quantitative measurement of fluorescence) and reverse transcriptase PCR, RT-PCR (using RNA rather than DNA). This technology allows the indirect detection of large groups of waterborne organisms and is recognized as a sensitivity method, a highly specific and potentially rapid detection method (Roldan et al. 2013). It is also considered a molecular source-tracking technique (Nobel and Weisberg 2005). Nevertheless, due to 
their high sensitivity, the amplification of contaminating polynucleotides can occur if careful procedures are not implemented and sample-specific substances can interfere with the PCR reaction and may seriously affect the detection limit. Furthermore, dead bacteria (e.g., autoclaved or disinfected) can still be detected by PCR, and under certain environmental conditions, false positives can be obtained. The relationship between PCR quantification and culture-based methods have been successfully used to quantify FIB at coastal and some inland water sites (Roldan et al. 2013). Oliver et al. (2014) discussed the suitability of molecular biological methods for the enumeration of regulatory microbial parameters (e.g., FIB) in bathing waters versus the use of traditional culture-based methods of current interest to regulators and the science community. The molecular methods, such as qPCR, may offer an extra value in providing a more rapid response for bathing water 'advisory' notices following known pollution events. Some of these methods can track the source of contamination through the use of specific biomarkers or through the presence of host-specific bacteria. However, as noted by Harwood et al. (2014) in their review on MST, often, the relative abundances of the selected genetic markers are not strongly correlated with FIB or with the pathogens for which they are supposed to be a proxy. However, future improvements on this method might lead to the resolution of this issue.

Another variant of PCR is the set of isothermal amplification techniques. These include (1) nucleic acid sequence-based amplification (NASBA), (2) transcriptionmediated amplification (TMA) and (3) loop-mediated isothermal amplification (LAMP). Because only a water bath or block heater is enough for DNA amplification since the method uses isothermal conditions and is suitable under field conditions (Notomi et al. 2000). The LAMP procedure is very simple and rapid wherein the amplification can be completed in less than $1 \mathrm{~h}$ under isothermal conditions employing a set of six specially designed primers spanning eight distinct sequences of a target gene, by incubating all the reagents in a single tube. Gene copy number can be visualized by the naked eye either as turbidity or in the form of a color change. Also, when reaction is combined with reverse transcription, RNA can be amplified as well (Parida et al. 2007). The developed LAMP technique is more specific, rapid and simple to perform than PCR, and the assay has successfully been applied for detection of bacterial, viral, fungal and protozoan diseases ( $\mathrm{He}$ et al. 2012; Gallas-Lindemann et al. 2016). Some are ready to use LAMP kits available in the market, such as those developed by Eiken Chemical Co. However, commercial availability for environmental waters application is needed. Other versions of LAMP technique have been developed, such as Micro LAMP, Lyophilized LAMP, Electric LAMP,
Multiplex LAMP (multiple targets detection) as well as Multiplex Reverse Transcription LAMP.

Finally, the DNA microarray technology, also known as DNA arrays, DNA chips or biochips, is another nucleic acid-based method which consists on the use of arrays of probes bound to a support (membrane or microchip). Amplified target DNA is hybridized with the bound probes and individual reactions are scored either using some electronic device, for example, a thin-film transistor sensor (Hu et al. 2017) or by image analysis. This technique is based on the identification of the genetic material of a microorganism in environmental samples, rather than relying on growing the microbe, or using a microscope. Large amounts of known genetic information can be stored on a very small surface and used to detect microbes in a sample by reacting with complementary DNA or RNA from the microbial population. The use of DNA microarrays has been employed to increase the speed and specificity of detection of FIB present in water bodies, namely in estuarine water (Zhou 2003). These techniques have been developed and they may become a viable option for routine analysis and may be useful for studies that characterize the identities and sources of microbiological contaminant. DNA microarrays such as Affymetrix, Corning and Agilent Technologies are commercially available.

\section{Enzymatic methods}

The enzymatic methods are based on the detection of specific enzymes, which are produced by target microorganisms and are involved in their specific metabolic pathway. If chromogenic substrates are used, this results in a distinct color change in the medium when it is hydrolyzed, whereas fluorogenic substrates produce a fluorescent product that can be detected under UV light. Based on these principles, a defined-substrate method was developed to reduce the long assay time of the conventional techniques. The indicator substrates are specifically designed for that vital nutrient source for the only target microbes. Other competitive bacteria cannot utilize the substrate and are therefore unable to interfere with the recovery of the target. This allows differentiating the target organisms from other bacteria that might grow on the selective media and therefore can eliminate the need for subculture and further biochemical tests to establish the identity of certain microorganisms. A number of enzyme-based methods are currently commercially available, such as Colilert ${ }^{\circledR}$, Enterolert $^{\circledR}$, m-ColiBlue ${ }^{\circledR}$, ColiComplete ${ }^{\circledR}$ and Chromocult $^{\circledR}$. These developments have led to changes in standard methods for enumerating FIB. The standard methods for the examination of water and wastewater (APHA 2005) recommend the mTEC method (an MF method based on defined-substrate technology, developed 
by the USEPA) for the detection and enumeration of $E$. coli at natural bathing beaches. The International Standards Organization published miniaturized MPN-based methods for coliforms $/ E$. coli and enterococci based on the definedsubstrate approach. However, these methods to RW require to be widely used. Furthermore, the enzyme-specific substrates can be used directly with water samples and incubated under optimum conditions for the enzyme in question without a cultivation step. In this case, the detection of target microorganism is based on direct measurement of cellular amount of enzymes by hydrolysis of a chromogenic or fluorogenic substrate, which can be detected by chemiluminescence and fluorescence instruments. The direct measurement of $\beta$-D-galactosidase or $\beta$-D-glucuronidase activity with fluorogenic substrates has been used as rapid surrogate parameters for estimating the level of coliform bacteria and E. coli in water samples. Some studies (Caruso et al. 2002; Lebaron et al. 2005) showed that microbial assessments of water given by this method and the ISO standard methods were in relatively good agreement for quantification of $E$. coli in marine waters. However, the enzymatic results were somewhat higher than those from the cultural procedure. An alternative way is to detect the fluorescent coliforms by solid-phase cytometry and different commercial applications such as Colifast CA100 and $\mathrm{ChemScan}^{\circledR}$. The rapid enzymatic assays are useful because they are simple and rapid and could be used for routine RW microbial quality assessment as well as incorporated into early fecal contamination warning systems (Henry et al. 2012).

\section{Emerging methods}

Despite the relevance of the techniques for detection and quantification of FIB discussed above, other biosensorbased methods have flourished in recent years (Bridle et al. 2014). A biosensor is defined as an analytical device incorporating a molecular recognition element associated or integrated with an electrochemical, optical, mass sensitive, calorimetric or magnetic transducer (Tothill 2011). Biosensing systems are based on a host of different platforms including liposome-immunoassays, microarrays, fluoroimmunoassays, and bioconjugated nanoparticle probes to bacteria (Bridle et al. 2014). Biosensors are seen as a competent and promising alternative to the above methods, aiming to modernize FIB detection techniques. This is because they can be developed inexpensively into sensitive, specific and easy-to-operate tools. They can also give very rapid readings, saving hours of sample analysis time compared to conventional methods (Altintas et al. 2015). The application of nanomaterials such as quantum dots, carbon nanotubes and smart nanostructures for the detection of indicator organisms using biosensors also plays an important role in increasing the sensitivity and capacity of these platforms. Besides biosensors, the integration of molecular technologies, such as sensors and microfluidic systems, is a promising alternative (Pires et al. 2014). Furthermore, these alternative techniques require extensive validation before they can be accepted for routine monitoring by regulatory and accreditation bodies. On the other hand, it is widely recognized that need is urgent for improving current detection methods, particularly in issues related to speed, sensitivity, specificity and online monitoring of hazardous bacteria, without the need for sophisticated equipment or skilled analysts and with a reduced cost.

A brief comparative analysis of conventional and alternative methods for assessment of microbial RW quality is given in Table 4. In general, most new methods are still under study, and require standardization and validation before becoming widely available. An overview of the future directions on the evaluation technology of microbiological quality of recreational water, in particular regarding the next-generation sequencing approaches can be found at Gomi et al. (2014) and Tan et al. (2015).

\section{Conclusions and future perspectives}

The safety of recreational waters is an important and timely issue specially when dealing with public health and sustainable water management, particularly in a context of climate changes. The number of hazardous microorganisms and forms present in RW is large and the regulatory agencies approach is guided by fecal contamination events. The limitation of traditional FIB, the regulatory approach and the potential effects of climate change on pathogenic organisms and human infectious diseases need an improvement of the indicator systems. It also requires establishing effective early warning systems allowing managers to take actions toward timely protection of RW users from exposure to waterborne pathogens. The effective response to such issues requires adequate indicators of microbial contamination, as well as the respective detection and quantification methods that allow the proper assessment of environmental waters. The new approach allows to complement the use of FIB analysis with the quantification of alternative microbial indicators, like fecal anaerobes or coliphages. The choice of the spectrum of indicators, in type and number, should be adapted to the specific local environment and should go beyond the international legislation. This approach induces the need for developing and improving the effective and efficient detection of microorganisms. Due to the limitations of current technology for microbiological water quality assessment, there is a need for alternative methods. With the development and incorporation of emerging molecular technologies 
Table 4 Strengths and weaknesses of conventional and some alternative microbiologic methods

\begin{tabular}{lll}
\hline Strengths & Weaknesses & $\begin{array}{l}\text { Status quo, future perspective, } \\
\text { capabilities needed }\end{array}$
\end{tabular}

\section{Conventional methods}

a. Most probable number

Sensitivity and reliability

The precision and sensitivity can be fitted

Flexible sample volume range

Applicable to all kinds of samples

Wide knowledge as indicators and surrogate parameters

Easy interpretation of test results and no special skills required

Media often inexpensive

b. Membrane filter

Easy to perform

Qualitative and quantitative results

Quantitative result and good precision if the number of colonies grown adequate

Differentiation and preliminary identification possible on selective media

Detection of bacteria occurring in low numbers

Further cultivation steps not always needed

\section{Alternative methods}

a. Molecular-immunological methods

Enzyme-linked immunosorbent assay

Qualitative and quantitative results

Rapid, robust, versatile simple to perform and sensitive test

Relatively specific for target organism

Immunofluorescent assay

Results can be available within the same day

Specific identification and detection at a single-cell level

b. Molecular-nucleic acid methods

Fluorescence in situ hybridization

Faster than cultivation methods and sensitive, safe test

Stability of the hybridization products

Allow radioactive labeling

Detection of VBNC and different microbes

Detect individual cells when ribosomal RNA is target

Can be used in combination with machines that do automated scanning of filter surfaces for fluorescent objects
Precision is often low, and not sufficiently specific (Adequate) selectivity of the medium adequate

High densities of no target bacteria may influence detection

Growth of the target organisms is influenced by sample inhibitors

Weak level of detection of slow-growing or stressed target bacteria

Long time required for sample analysis and difficult automation

Possible adsorption of particles that may interfere with the growth of the target organism

Not all bacteria can be cultivated

Selectivity for certain indicators often not sufficient

Lack of application on turbid samples

Time-consuming and no information on infectivity of a pathogen

Scoring of typical colonies not always easy

Cross-reacting antibodies (low selectivity)

Specificity of the antibody used, and their concentration and antigen

Need for a pre-enrichment to reduce the cell surface antigen

Low sensitivity

Limited application with high levels of non-targeted microorganism

Without pre-cultivation, currently no discrimination between viable and non-viable microorganisms

No information on infectivity of a pathogen

Existence of a threshold below which the method cannot be applied (when specific bacteria were below $1 \%$ of the total population)

Selectivity can be a problem due to cross-reacting antibodies

No information on the viability of the organisms

Samples need to be concentrated

Detection is strictly taxonomic and requires specific and expensive equipment

Lack of sensitivity with chromosomal genes or mRNA as target

Not applicable to detect 1 indicator per $100 \mathrm{ml}$ without concentration

Can be inconclusive

The design of a specific and unambiguously restrictive probe for a certain group of microorganisms is not always possible

The design and optimization of hybridization conditions for a new probe is a slow and difficult process
Standardized (ISO, CEN, APHA)

Improved media might be developed in order to obtain faster growth and to increase sensitivity and selectivity

General microbiology laboratory

\section{Standardized}

Improved media might be developed in order to obtain faster growth and to increase sensitivity and selectivity

General microbiology laboratory

\section{Frequently used}

Assays allow standardization and automation

Specialized microbiology laboratory

\section{Frequently used}

Further research to develop variants of this method with applications in environmental matrices

Specialized microbiology laboratory

Used with some frequency

Assays allow standardization and automation

Specialized microbiology laboratory 
Table 4 continued

\begin{tabular}{|c|c|c|}
\hline Strengths & Weaknesses & $\begin{array}{l}\text { Status quo, future perspective, capabilities } \\
\text { needed }\end{array}$ \\
\hline \multicolumn{3}{|l|}{ Polymerase chain reaction } \\
\hline Rapid, flexible, and cost effective of the & Limited reliability & Innovative, not yet routine \\
\hline $\begin{array}{l}\text { molecular methods } \\
\text { Sensitive, selective and specific }\end{array}$ & $\begin{array}{l}\text { Sufficient quantity of nucleic acids from the targeted } \\
\text { microbe has to be recovered }\end{array}$ & $\begin{array}{l}\text { Potential for the routine assays and } \\
\text { automation }\end{array}$ \\
\hline Detection of VBNC microorganisms & Negatively affected by certain environmental conditions & Specialized microbiology laboratory \\
\hline Sound basis for further analyses of nucleic & Difficulty on getting primers to a specified group & \\
\hline $\begin{array}{l}\text { acids } \\
\text { Allows the indirect detection of large of } \\
\text { waterborne hazards }\end{array}$ & $\begin{array}{l}\text { The sensitivity of PCR reaction might depending on } \\
\text { thermocyclers and reagents used from different suppliers } \\
\text { and samples have, in most cases, to be concentrated }\end{array}$ & \\
\hline $\begin{array}{l}\text { RT-PCR technique allows assessing } \\
\text { viability of cells }\end{array}$ & $\begin{array}{l}\text { Basic procedure does not allow quantitation of the number } \\
\text { of amplifiable DNA/RNA fragments }\end{array}$ & \\
\hline & No information of infectivity of a pathogen & \\
\hline \multicolumn{3}{|l|}{ DNA microarrays } \\
\hline $\begin{array}{l}\text { Allow testing of up to several thousand } \\
\text { sequences in one assay on a single } \\
\text { "chip" } \\
\text { Sensitive, selective and specific to the } \\
\text { desired level to detection } \\
\text { Fast ( } 2-4 \mathrm{~h})\end{array}$ & $\begin{array}{l}\text { Optimize the stringency of the analysis conditions for } \\
\text { simultaneous hybridization of multiple probes } \\
\text { Absolute quantitation might be problematic } \\
\text { No indication of viability of the microorganism } \\
\text { Highly trained personnel, the specialized and cost } \\
\text { equipment }\end{array}$ & $\begin{array}{l}\text { At research stage } \\
\text { Potential for automation } \\
\text { Specialized microbiology laboratory }\end{array}$ \\
\hline \multicolumn{3}{|l|}{ c. Enzymatic methods } \\
\hline $\begin{array}{l}\text { Easy to use, do not require skilled } \\
\text { personnel nor unsophisticated } \\
\text { equipment, fast }(1 \mathrm{~h}) \text { and sensitive test } \\
\text { Give a more rapid and realistic estimate of }\end{array}$ & $\begin{array}{l}\text { Problems linked to the presence of non-culturable indicator } \\
\text { bacteria for techniques based on the defined-substrate } \\
\text { technology }\end{array}$ & $\begin{array}{l}\text { Not yet a routine task } \\
\text { Potential for the routine assays and } \\
\text { automation; can be integrated an early } \\
\text { warning system }\end{array}$ \\
\hline $\begin{array}{l}\text { Give a more rapid and realistic estımate of } \\
\text { FIB than classical culture-based methods } \\
\text { Rapid assays performed without any }\end{array}$ & the prior growth of target microorganism and has a high & General microbiology laboratory \\
\hline $\begin{array}{l}\text { Rapid assays performed without any } \\
\text { cultivation step used direct determination } \\
\text { of enzymatic activity by fluorimeter }\end{array}$ & $\begin{array}{l}\text { May show some non-specificity with regard to target } \\
\text { analyses }\end{array}$ & \\
\hline \multicolumn{3}{|l|}{$\begin{array}{l}\text { Detection of VBNC microorganisms and } \\
\text { different microbes }\end{array}$} \\
\hline \multicolumn{3}{|l|}{$\begin{array}{l}\text { Useful in situations where water quality } \\
\text { changes rapidly }\end{array}$} \\
\hline $\begin{array}{l}\text { May be the first rapid methods adopted by } \\
\text { regulatory agencies }\end{array}$ & & \\
\hline
\end{tabular}

Adapted from: Zhou (2003), Garcia-Armisen and Servais (2004), Nobel and Weisberg (2005), Zourob et al. (2008), Roldan et al. (2013), Harwood et al. (2014), Oliver et al. (2014) and Castillo et al. (2015)

in microbiological analyses of water, the currently available methods are expected to become more rapid, accurate, specific, sensitive and robust. However, most of the new techniques are expensive and require sophisticated detection instruments which may remain a limitation for smaller laboratories and unattractive for field use and early warning systems application. The new biosensing methodologies represent a promising approach for future developments in the RW quality monitoring. The next-generation sequencing approaches will most likely impose a change on the definition of indicator systems and microbiological guidelines. Extensive information on the microbiota of natural water bodies is becoming available, in parallel with the characterization of gut microbiota of man and of many other warmblooded animals. That will allow the identification of the most representative indicators for risk assessments and source tracking. In addition, the massive sequencing of genomes and metagenomes will provide the bases for the identification of genetic markers. Despite the fact that these alternative methods would make an important contribution to design and implement measures of fecal contamination control and mitigation, they still need validation before they can be accepted in routine monitoring by regulatory and accreditation bodies.

Finally, it should be stressed that the pathogen indicators, as well as their quantification methods, need to be improved to allow more affordable and effective water quality control and to reduce the health risk.

Acknowledgements This review article was not supported by any grant or funding. The authors wish to thank the anonymous reviewers for their contributions to the manuscript. The authors are also grateful to Kamel MAALOUL, translator and English professor, for having proofread the manuscript. 


\section{Compliance with ethical standards}

Conflict of interest On behalf of all authors, the corresponding author states that there is no conflict of interest.

\section{References}

Ahmed W, Vieritz A, Goonetilleke A, Gardner T (2010) Health risk from the use of roof-harvested rainwater in Southeast Queensland, Australia, as potable or non potable water, determined using quantitative microbial risk assessment. Appl Environ Microbiol 76(22):7382-7391. doi:10.1128/AEM.00944-10

Altintas Z, Gittens M, Pocock J, Tothill IE (2015) Biosensors for waterborne viruses: detection and removal. Biochimie 115:144-154. doi:10.1016/j.biochi.2015.05.010

ANZECC (2000) Australian and New Zealand Guidelines for Fresh and Marine Water Quality 2000. http://www.environment.gov.au/ resource/australian-and-new-zealand-guidelines-fresh-and-marinewater-quality-volume-1-guidelines. Accessed 8 July 2015

APHA (2005) Standard methods for the examination of water and wastewater, 21st edition, 21st edn. American Public Health Association, American Water Works Association and Water Environment Federation, Washington, DC

Boehm AB, Sassoubre LM (2014) Enterococci as indicators of environmental fecal contamination. Enterococci: from commensals to leading causes of drug resistant infection. Gilmore MS, Clewell DB, Ike Y et al. (eds) 71-86. http://www.ncbi.nlm.nih. gov/books/NBK190421/ Accessed 24 March 2015

Bouzid M (2016) Waterborne diseases and climate change: Impact and Implications. Examining the Role of Environmental Change on Emerging Infectious Diseases and Pandemics. IGI Global Eds, Hershey PA

Bridle H, Miller B, Desmulliez MPY (2014) Microfluidics in waterborne pathogen monitoring: a review. Water Res 55:256-271. doi:10.1016/j.watres.2014.01.061

Byappanahalli MN, Shively DA, Nevers MB, Sadowsky MJ, Whitman RL (2003) Growth and survival of Escherichia coli and enterococci populations in the macro-alga Cladophora (Chlorophyta). FEMS Microbiol Ecol 46(2):203-211. doi:10. 1016/S0168-6496(03)00214-9

Byappanahalli MN, Nevers MB, Korajkic A, Staley ZR, Harwood VJ (2012) Enterococci in the Environment. Microbiol Mol Biol Rev 76(4):685-705. doi:10.1128/MMBR.00023-12

Cabral JPS (2010) Water microbiology. bacterial pathogens and water. Int J Environ Res Publ Health 7(10):3657-3703. doi:10. 3390/ijerph7103657

Caruso G, Zaccone R, Crisafi E (2000) Use of the indirect immunofluorescence method for detection and enumeration of Escherichia coli in seawater samples. Lett Appl Microbiol 31(4):274-278. doi:10.1046/j.1472-765x.2000.00810.x

Caruso G, Crisafi E, Mancuso M (2002) Development of an enzyme assay for rapid assessment of Escherichia coli in seawaters. J Appl Microbiol 93(9):548-556. doi:10.1046/j.1365-2672.2002. 01729.x

Castillo FYR, Muro AL, Jacques M, Garneau P, González FJA, Harel $J$ et al (2015) Waterborne Pathogens: detection Methods and Challenges. Pathogens 4(2):307-334. doi:10.3390/ pathogens 4020307

CCREM (1991) Guidelines for Canadian Recreational Water Quality. Health Canada, Ottawa, Ontario. http://www.hc-sc.gc.ca/ewhsemt/water-eau/recreat/index-eng.php. Accessed 30 Jan 2015

Coffey R, Benham B, Krometis L-A, Wolfe ML, Cummins E (2014) Assessing the Effects of Climate Change on Waterborne Microorganisms: implications for EU and US Water Policy.
Hum Ecol Risk Assess 20(3):724-742. doi:10.1080/10807039. 2013.802583

Converse RR, Blackwood AD, Kirs M, Griffith JF, Noble RT (2009) Rapid QPCR-based assay for fecal Bacteroides spp. as a tool for assessing fecal contamination in recreational waters. Water Res 43(19):4828-4837. doi:10.1016/j.watres.2009.06. 036

Cook KL, Bolster CH (2007) Survival of Campylobacter jejuni and Escherichia coli in groundwater during prolonged starvation at low temperatures. J Appl Microbiol 103(3):573-583. doi:10. 1111/j.1365-2672.2006.03285.x

Dorevitch S, Dworkin MS, DeFlorio SA, Janda WM et al (2012) Enteric pathogens in stool samples of Chicago-area water recreators with new-onset gastrointestinal symptoms. Water Res 46(16):4961-4972. doi:10.1016/j.watres.2012.06.030

Ferguson D, Signoretto C (2011) Environmental persistence and naturalization of fecal indicator organisms. Microbial source tracking: methods, applications, and case studies, 379-397. Springer, New York. doi:10.1007/978-1-4419-9386-1_17

Field KG, Samadpour M (2007) Fecal source tracking, the indicator paradigm, and managing water quality. Water Res 41(16):3517-3538. doi:10.1016/j.watres.2007.06.056

Gallas-Lindemann C, Sotiriadou I, Plutzer J et al (2016) Giardia and Cryptosporidium spp. dissemination during wastewater treatment and comparative detection via immunofluorescence assay (IFA), nested polymerase chain reaction (nested PCR) and loop mediated isothermal amplification (LAMP). Acta Trop 158:43-51. doi:10.1016/j.actatropica.2016.02.005

Garcia-Armisen T, Servais P (2004) Enumeration of viable E. coli in rivers and wastewaters by fluorescent in situ hybridization. J Microbiol Methods 58:269-279. doi:10.1016/j.mimet.2004.04. 014

Gilbride K (2014) Molecular methods for the detection of waterborne pathogens. In: Bridle, $\mathrm{H}$ (ed) Elsevier B.V Waterborne pathogens, detection methods and applications. London, UK, 231-290

Gomi R, Matsuda T, Matsui Y, Yoneda M (2014) Fecal source tracking in water by next-generation sequencing technologies using host-specific escherichia coli genetic markers. Environ Sci Technol 48(16):9616-9623. doi:10.1021/es501944c

Halliday E, Gast RJ (2011) Bacteria in beach sands: an emerging challenge in protecting coastal water quality and bather health. Environ Sci Technol 45(2):370-379. doi:10.1021/es102747s

Harwood VJ, Levine AD, Scott TM, Chivukula V et al (2005) Validity of the indicator organism paradigm for pathogen reduction in reclaimed water and public health protection. Appl Environ Microbiol 71(6):3163-3170. doi:10.1128/AEM.71.6. 3163-3170.2005

Harwood VJ, Staley C, Badgley BD, Borges K, Korajkic A (2014) Microbial source tracking markers for detection of fecal contamination in environmental waters: relationships between pathogens and human health outcomes. FEMS Microbiol Rev 38(1):1-40. doi:10.1111/1574-6976.12031

He X, Wei Y, Cheng L, Zhang D, Wang Z (2012) Molecular detection of three gastroenteritis viruses in urban surface waters in Beijing and correlation with levels of fecal indicator bacteria. Environ Monit Assess 184(9):5563-5570. doi:10.1007/s10661-011-23626

Health Canada (2006) Bacterial waterborne pathogens-current and emerging organisms of concern. Health Canada, Ottawa, Ontario. http://www.hc-sc.gc.ca/ewh-semt/consult/_2011/ecoli/ index-eng.php. Accessed 25 Jan 2015

Health Canada (2012) Guidelines for Canadian Recreational Water Quality-Third edition. Health Canada, Ottawa, Ontario. http:// www.hc-sc.gc.ca/ewh-semt/pubs/water-eau/guide_water-2012guide_eau/index-eng.php. Accessed 25 Jan 2015 
Hellein KN, Battie C, Tauchman E, Lund D et al (2011) Culturebased indicators of fecal contamination and molecular microbial indicators rarely correlate with Campylobacter spp. in recreational waters. J Water Health 9(4):695-707. doi:10.2166/wh. 2011.154

Henry A, Scherpereel G, Brown R, Baudart J, Servais P, Tabassi NCB (2012) Comparison of rapid methods for active bathing water quality monitoring. In: Kay D, Fricker C (eds) The significance of faecal indicators in water, a global perspective. doi:10.1039/ 9781849735421

Hot D, Legeay O, Jacques J, Gantzer C, Caudrelier Y, Guyard K et al (2003) Detection of somatic phages, infectious enteroviruses and enterovirus genomes as indicators of human enteric viral pollution in surface water. Water Res 37:4703-4710. doi:10. 1016/S0043-1354(03)00439-1

Hu C, Kalsi S, Zeimpekis I, Sun K, Ashburn P et al (2017) Ultra-fast electronic detection of antimicrobial resistance genes using isothermal amplification and thin film transistor sensors. Biosens Bioelectron 96:281-287

ISO (1998a) Water quality-detection and enumeration of intestinal enterococci in surface and waste water-Part 1: Miniaturized method (most probable number) by inoculation in liquid medium. Geneva, International Organization for Standardization (ISO/FDIS 7899-1)

ISO (1998b) Water quality-detection and enumeration of Escherichia coli and coliform bacteria in surface and waste water-Part 3: Miniaturized method (most probable number) by inoculation in liquid medium. Geneva, International Organization for Standardization (ISO/FDIS 9308-3)

Johnston C, Ufnar JA, Griffith JF, Gooch JA, Stewart JR (2010) A real-time qPCR assay for the detection of the nifH gene of Methanobrevibacter smithii, a potential indicator of sewage pollution. J Appl Microbiol 109(6):1946-1956. doi:10.1111/j. 1365-2672.2010.04824.x

Lebaron P, Henry A, Lepeuple AS, Pena G, Servais P (2005) An operational method for the real-time monitoring of $E$. coli numbers in bathing waters. Mar Pollut Bull 50(6):652-659. doi:10.1016/j.marpolbul.2005.01.016

Lemarchand K, Lebaron P (2003) Occurrence of Salmonella spp. and Cryptosporidium spp. in a French coastal watershed: relationship with fecal indicators. FEMS Microbiol Lett 218(1):203-209. doi:10.1016/S0378-1097(02)01135-7

Llivina LM, Lucena F, Jofre J (2005) Enteroviruses and bacteriophages in bathing waters. Appl Environ Microbiol 71(11):6838-6844. doi:10.1128/AEM.71.11.6838-6844.2005

Mclellan SL, Newton RJ, Vandewalle JL, Shanks OC et al (2013) Sewage reflects the distribution of human fecal lachnospiraceae. Environ Microbiol 15(8):2213-2227. doi:10.1111/1462-2920. 12092

Nobel RT, Weisberg SB (2005) A review of technologies for rapid detection of bacteria in recreational waters. J Water Health 3(4):381-392. doi:10.2166/wh.2005.051

Notomi T, Okayama H, Masubuchi H, Yonekawa T, Watanabe K, Amino N, Hase T (2000) Loop-mediated isothermal amplification of DNA. Nucleic Acids Res 28(12):E63

Ogden ID, Dallas JF, MacRai M, Rotariu O et al (2009) Campylobacter excreted into the environment by animal sources: prevalence, concentration shed, and host association. Foodborne Pathogens Dis 6(10):1161-1170. doi:10.1089/fpd.2009.0327

Oliver JD (2015) The biology of Vibrio vulnificus. Microbiol Spectr 3(3):1-10. doi:10.1128/microbiolspec

Oliver DM, van Niekerk M, Kay D, Heathwaite AL, Porter J et al (2014) Opportunities and limitations of molecular methods for quantifying microbial compliance parameters in EU bathing waters. Environ Int 64:124-128. doi:10.1016/j.envint.2013.12. 016
Pandey PK, Soupir ML, Haddad M, Rothwell JJ (2012) Assessing the impacts of watershed indexes and precipitation on spatial instream E. coli concentrations. Ecol Ind 23:641-652. doi:10.1016/ j.ecolind.2012.05.023

Parida MM, Santhosh SR, Dash PK, Tripathi NK et al (2007) Rapid and real-time detection of chikungunya virus by reverse transcription loop-mediated isothermal amplification. J Clin Microbiol 45(2):351-357. doi:10.1128/JCM.01734-06

Payment P, Waite M, Dufour A (2010) Introducing parameters for the assessment of drinking water quality. World Health Organization, Geneva, Switzerland. http://www.who.int/water_sanita tion_health/dwq/9241546301_chap2.pdf. Accessed 20 March 2015

Pires NM, Dong T, Hanke U, Hoivik N (2014) Recent developments in optical detection technologies in lab-on-a chip devices for biosensing applications. Sensors 14(8):15458-15479. doi:10. 3390/s140815458

Pond K (2005) Water Recreation and Disease. World Health Organization, Geneva, Switzerland. http://www.who.int/water sanitation_health/bathing/recreadis.pdf. Accessed 10 Feb 2015

Roldan RL, Tusell P, Courtois S, Cortina JL (2013) On-line bacteriological detection in water. Trends Anal Chem 44:46-57. doi:10.1016/j.trac.2012.10.010

Russel DA, Walling JP (2007) Waterborne pathogens in urban watersheds. J Water Health 5(1):149-162. doi:10.2166/wh.2006. 001

Sabino R, Rodrigues R, Costa I, Carneiro C, Cunha M et al (2014) Routine Routine screening of harmful microorganisms in beach sands: implications to public health. Sci Total Environ 472:1062-1069. doi:10.1016/j.scitotenv.2013.11.091

Savichtcheva O, Okabe S (2006) Alternative indicators of fecal pollution: relations with pathogens and conventional indicators, current methodologies for direct pathogen monitoring and future application perspectives. Water Res 40(13):2463-2476. doi:10. 1016/j.watres.2006.04.040

Tan B, Ng C, Nshimyimana JP, Loh LL, Gin KY-H, Thompson JR (2015) Next-generation sequencing (NGS) for assessment of microbial water quality: current progress, challenges, and future opportunities. Frontiers in Microbiology 6, article 1027: 1-20. doi:10.3389/fmicb.2015.01027

Tothill IE (2011) Biosensors and nanomaterials and their application for mycotoxin determination. World Mycotoxin J 4(4):361-374. doi:10.3920/WMJ2011.1318

USEPA (1986) EPA's Ambient Water Quality Criteria for Bacteria1986. Report EPA440/5-84-002. http://water.epa.gov/scitech/ swguidance/standards/upload/2001_10_12_criteria_ambientwqc_ bacteria1986.pdf. Accessed 12 Mar 2015

USEPA (2012) Recreational water quality criteria_Draft. Report of Office of Water 820-D-11-002. http://water.epa.gov/scitech/sw guidance/standards/criteria/health/recreation/upload/recreation document_draft.pdf. Accessed 12 Mar 2015

Wade TJ, Calderon RL, Sams E, Beach M et al (2006) Rapidly measured indicators of recreational water quality are predictive of swimming-associated gastrointestinal illness. Environ Health Perspect 114(1):24-28

Whitman RL, Harwood VJ, Edge TA, Nevers MB, Byappanahalli M, Vijayavel K (2014) Microbes in beach sands: integrating environment, ecology and public health. Rev Environ Sci Biotechnol 13(3):329-368. doi:10.1007/s11157-014-9340-8

WHO (2003) Guidelines for safe recreational water environments. Volume 1: Coastal and fresh waters. World Health Organization, Geneva, Switzerland. http://www.who.int/water_sanitation health/bathing/srwe1/en/. Accessed 12 Mar 2015

WHO (2012) Animal Waste, Water Quality and Human Health. Edited by Dufour A., Bartram J., Bos R. and Gannon V.. Published on behalf of World Health Organization by IWA 
Publishing, London. http://www.who.int/water_sanitation_ health/publications/2012/animal_waste/en/. Accessed 12 Mar 2015

Wu J, Long SC, Das D, Dorner SM (2011) Are microbial indicators and pathogens correlated? A statistical analysis of 40 years of research. J Water Health 9(2):265-278. doi:10.2166/wh.2011. 117
Zhou J (2003) Microarrays for bacterial detection and microbial community analysis. Curr Opin Microbiol 6:288-294. doi:10. 1016/S1369-5274(03)00052-3

Zourob M, Elwary S, Turner APF (2008) Principles of bacterial detection: biosensors, recognition receptors and microsystems. Springer, London 